Article

\title{
Trade-Offs between Human and Environment: Challenges for Regional Water Management under Changing Conditions
}

\author{
Elmira Hassanzadeh $\mathbb{D}$ \\ Department of Civil, Geological, and Mining Engineering, Polytechnique Montreal, Montreal, QC H3T 1J4, \\ Canada; elmira.hassanzadeh@polymtl.ca; Tel.: +1-(514)-340-4711 (ext. 5233)
}

Received: 8 July 2019; Accepted: 22 August 2019; Published: 26 August 2019

\begin{abstract}
Water resource systems are under unprecedented pressure mainly due to rapid socio-economic growth, weak water and land management decisions, as well as variability and change in climate conditions. These pressures have disrupted the functionality of freshwater ecosystems and have generated water management challenges in various regions across the globe. Here, we showcase the potential trade-offs in the Province of Saskatchewan, Canada, between upstream human activities and downstream environmental needs under changing water availability conditions. We showed that an increase in irrigation areas can boost provincial economy but alter timing, magnitude and rhythmicity of the peak flows reaching downstream ecosystems. This indicates that the business as usual management might not be able to handle such emerging challenges. To improve water management, we argue that there is a need to better represent the dynamic interactions between human water use and water quantity and quality conditions and their influence on ecosystems. In addition, impact assessment frameworks need to be improved to better identify system vulnerabilities under changing natural and anthropogenic conditions. Moreover, due to the key role of stakeholders in adopting land and water management decisions, their viewpoints need to be understood and included in management decisions.
\end{abstract}

Keywords: water resource management; anthropogenic effects; changing water availability; vulnerability assessment; freshwater ecosystems; Saskatchewan River Basin

\section{Introduction}

Streamflow regime plays a key role in shaping the structure and health of water environments [1]. Human activities directly and indirectly have disrupted the natural water system conditions and have put enormous pressure on freshwater ecosystems [2-4]. As an example, extensive water withdrawals to fulfill food and energy needs of growing population in the "Anthropocene" have considerably reduced water availability across the globe [5-7]. Moreover, water management coupled with land use and land management activities have altered natural streamflow regime and sediment transports, with negative impacts on downstream water environments [8-10]. Such activities have also directly introduced pollution to freshwater resources and degraded ecosystems [11-14]. In particular, human viewpoints towards overexploitation of water resources to "make money from every drop" have considerably influenced water and land management decisions to favor economic growth, without leaving much high-quality water for the downstream environments [15-19]. This disruption in natural environments, in turn, has caused irreversible consequences for both human and ecosystem in various regions since last century [20,21]. One of the vivid examples for this situation is the drying Lake Urmia in Iran. This UNESCO biosphere reserve includes more than 100 islands, which are home to various plant, animal and bird species $[22,23]$. Over the past couple of decades, upstream human water withdrawals have 
considerably reduced the water availability reaching the Lake Urmia [24-26] and caused ecosystem decline in this area $[27,28]$.

In addition to direct impacts, human activities have considerably increased the heat trapping gasses and contributed to global warming [29]. Changes in climate can alter hydrological processes, e.g., characteristics of precipitation, as well as timing and volume of snow and glacier melt, which can majorly affect water availability conditions across various scales [30-32]. It can also increase human water demand, e.g., for irrigated agriculture, particularly in arid regions [33,34]. In addition to impacts on the streamflow regime, a warming climate can increase water temperature and deteriorate water quality conditions, particularly in the areas with low flow conditions, and affect the water environments [35]. The compound effects of these changing natural and anthropogenic conditions on water system elements can introduce new challenges for regional water management [36,37].

The objective of this study is to show the emerging trade-offs between upstream human activities and downstream ecosystem needs in a Canadian water resource system under changing water availability conditions, with a greater goal of identifying strategies to address similar water management challenge. We focused on the Saskatchewan River Basin (SaskRB) in the Province of Saskatchewan. Water availability in Saskatchewan is mainly supported by the South and North Saskatchewan River (SSR and NSR, respectively) flows, which originate from the Rocky Mountains in the neighboring province of Alberta [38]. Water in Saskatchewan is used for various activities such as power generation and agricultural production. The remaining water reaches the downstream Saskatchewan River Delta (SRD), one of the largest inland deltas in North America and home to First Nations and Metis communities [39]. The SRD includes rich terrestrial and aquatic ecosystems and is a globally significant bird area in Canada [40]. Water resource management in Saskatchewan is facing new challenges. In brief, warming climate and major water withdrawals in Alberta have altered streamflow regime of SSR and NSR flows, reaching Saskatchewan [41,42]. In addition, Saskatchewan is planning to expand irrigated agricultural areas by $400 \%$ to potentially boost sectorial and provincial economy [43]. In this study, we assessed the performance of the water resource system in Saskatchewan, under possible changes in NSR and SSR flow series and agricultural development scenarios. The structure of the paper is as follows. The study area and applied impact assessment framework are explained in Sections 2 and 3, respectively. The results are presented and discussed in Section 4. Current challenges and opportunities to improve water resource management are discussed in Section 5. Finally, the paper is concluded in Section 6.

\section{Case Study}

The SaskRB in the province of Saskatchewan is shown in Figure 1. The SSR and NSR flows reaching Saskatchewan have the long-term annual discharges of $213 \mathrm{~m}^{3} / \mathrm{s}$ and $215 \mathrm{~m}^{3} / \mathrm{s}$, respectively [44]. The SSR flow is heavily regulated by Lake Diefenbaker to support irrigated agriculture, industry, hydropower as well as rural and urban water uses [45]. The regulated SSR flows through the $186 \mathrm{MW}$ Coteau Creek hydropower plant, passes through the City of Saskatoon, the largest city in the province, and after meeting multiple demands on its way, confluences with the NSR, and forms the Saskatchewan River (SR) [46]. The SR, with a long-term annual discharge of $421 \mathrm{~m}^{3} / \mathrm{s}$, after meeting water for 255 MW Codette and 288 MW Tobin hydropower plants, passes through the SRD [47]. The SRD covers approximately $10,000 \mathrm{~km}^{2}$ and contains hydrographic networks of rivers, lakes and wetlands [48]. The SRD has a diverse vegetation coverage and is home to a variety of native and migrating species [49]. The livelihood of aboriginal communities in this area depends on the health and biodiversity of this ecosystem.

The water resource system in Saskatchewan is facing new water security challenges. As Saskatchewan is heavily dependent on the availability of water in Alberta, any changes in Alberta's streamflow conditions can affect Saskatchewan's socio-economic activities and environment. Over the past few decades, water withdrawals mainly for irrigation purposes and extensive water regulations in Alberta have significantly affected the natural characteristics of SSR and NSR flows reaching Saskatchewan. 
Moreover, warming climate has affected the volume and timing of the snow and glacier melt in the Canadian Rocky Mountains [50], with major impacts on SSR and NSR flows [41,50,51]. In addition, Saskatchewan is investigating to increase current irrigated area by $400 \%$. Earlier investigations have showed that Lake Diefenbaker has the capacity to support water to this sector, without causing problem for local water users [52].

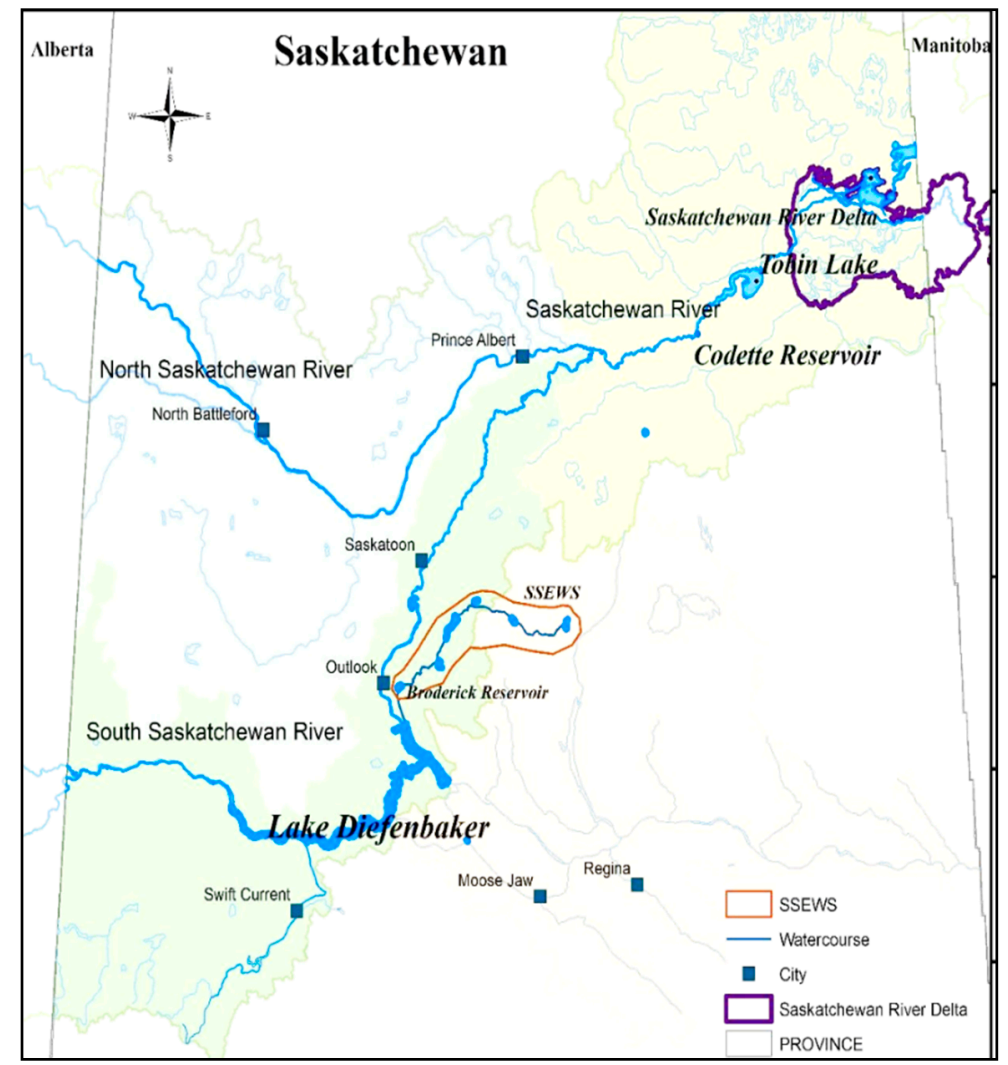

Figure 1. The Saskatchewan River Basin (SaskRB) in Saskatchewan, Canada.

\section{Impact Assessment under Changing Conditions}

In this study, our objective is to shed light on the potential tradeoffs between upstream economic developments and downstream environmental needs in Saskatchewan under possible changes in regional water availability and irrigation expansion. For this purpose, we used (1) a water resource system model to simulate the behavior of the SaskRB; (2) an ensemble of SSR and NSR flow time series to represent possible changes in upstream streamflow conditions; and (3) a set of economic and ecohydrological indicators to represent water system performance under changing conditions. These three components of our analysis are described below. It should be noted that the impact of changing upstream conditions on the provincial economy and ecosystem of the SRD is separately assessed in $[53,54]$, respectively. However, the trade-offs between these sectors have not been investigated holistically. Moreover, the results of $[53,54]$ cannot be merged or compared due to the application of different procedure for the calibration of the water resource model, explained below. Therefore, here, we formally presented the trade-offs between economic development and ecosystem of the delta using the last version of the water resource system model.

\subsection{Representation of the Regional Water Resource System}

The Sustainability-oriented Water Allocation, Management and Planning model (SWAMPSK), developed by the author is used in this study to simulate the water resource system in Saskatchewan.

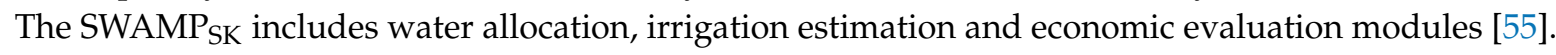


The model allocates water to different users such as hydropower and irrigated agriculture at weekly time scale considering water availability and demand conditions, water allocation priorities and system physical properties. It should be noted that water allocation policies in this province are not based on "first in time, first in right", which indicates license holders will be affected by water shortage regardless of their license issuance date [56]. However, higher allocation priorities are given to municipal and industrial sectors followed by irrigated agriculture and hydropower and other sectors. These priorities have been formulated in the model using if-then-rule functions. Due to the importance of agriculture in this region, the model estimates irrigation water demand dynamically for key crops in this region considering the agricultural area, irrigation efficiency, climatic conditions, antecedent irrigation water supply and soil-moisture conditions. Moreover, the model estimates annual Net Benefits (NBs) for irrigated agriculture and hydropower, which are key water-dependent economic sectors in the province. Hydropower NB is estimated based on the annual cost of power production (e.g., cost of repair and maintenance), annual price of electricity and total electricity production in Coteau Creek, E.B. Campbell and Nipawin power plants. Agricultural NBs are estimated for each crop based on the annual cost of crop production in the area (e.g., cost of fertilizer, seeds), crop price, as well as crop yield [55]. The crop yield is calculated annually using the developed soil-moisture module. The earlier version of the model is calibrated based on the output of an existing water resource model for this region [53]. The model accuracy is further improved and recalibrated to better represent observed streamflow series in Saskatoon and before entering the SRD from 1981 to 2010 [54]. The observed data for model development and calibration during 1980-2010 are obtained from the following sources: for climate (Government of Canada; http://climate.weather.gc.ca/), streamflow (Government of Canada; https://wateroffice.ec.gc.ca), agriculture production and costs (Saskatchewan Ministry of Agriculture; https://saskatchewan.ca), power production and costs (Saskpower; https://www.saskpower.com/) and system physical properties and water allocation priorities (Water Security Agency; https://www.wsask.ca/).

Here, the water resource system model used in [54] is adopted and slightly improved by updating the reservoir operational rule curves in Lake Diefenbaker, based on recent information obtained from the Saskatchewan Water Security Agency. The performance of the model is compared with observed SSR flow at the City of Saskatoon (gauge 05HG001) and SR flow before entering the delta (gauge 05KD003) during 1980-2010 in Table 1. As is apparent, the model can simulate the performance of this water system with acceptable accuracy.

Table 1. The performance of the water resource system model in representing the flows in Saskatoon and before entering the Saskatchewan River Delta (SRD) during the observed period of 1980-2010. SR: Saskatchewan River; SSR: South Saskatchewan River.

\begin{tabular}{cccc}
\hline Variable/Performance & $\begin{array}{c}\text { Root Mean Square } \\
\text { Error }\left(\mathbf{m}^{\mathbf{3}} / \mathbf{s}\right)\end{array}$ & $\begin{array}{c}\text { Correlation } \\
\text { Coefficient }\end{array}$ & $\begin{array}{c}\text { Mean Absolute } \\
\text { Relative Error }\end{array}$ \\
\hline SSR flow in Saskatoon & 85 & 0.81 & 0.35 \\
SR flow entering the SRD & 135 & 0.85 & 0.24 \\
\hline
\end{tabular}

\subsection{Representation of Changing Water Availability}

For impact assessment analysis, we used an ensemble of stochastically generated NSR and SSR flow time series, which correspond to possible changes in the streamflow regime in Alberta. The methodology for stochastic generation of streamflow series is explained in detail in [57] and is used in $[53,54,58]$ for system vulnerability assessment. In brief, using this approach, first a predefined range of changes in annual flow volume and peak flow timing is identified. Second, change factors, which correspond to the predefined alterations in streamflow regime, are applied to streamflow distributions using quantile mapping [59]. Few studies have used an ensemble of Global Climate Model projections (GCMs) to understand the impact of climate change on SSR and NSR flow regime in Alberta [41,50,60-63]. While their estimated magnitude of change in flow regime is not similar, their projected boundary of change ranged from $-23 \%$ to $15 \%$ for NSR, and from $-22 \%$ to $8 \%$ for SSR flow 
volume in the future. These studies also indicated that warmer climate can cause shorter and warmer winters, earlier snow and glacier melts, as well as alterations in spring and summer peak flow timing. Having said that, there is a large uncertainty associated with these projections due to uncertainties in GCMs and hydrological models [64]. Moreover, the compound impact of changing natural and anthropogenic conditions on NSR and SSR flow regime have not been studied yet. Therefore, we considered a wider range of $-25 \%,-20 \%, \ldots$, to $20 \%, 25 \%$ changes in NSR and SSR annual flow volume as well as $-5,-4, \ldots$ to 7,8 weeks shifts in annual peak flow timing to fully understand system performance under possible changes in upstream flow series. Having this range, in total, $154(11 \times 14)$ streamflow conditions are considered for stochastic sampling. For each of the 154 changing streamflow conditions, 100 realizations are generated to represent natural variability in the SSR and NSR flow series. Therefore, in total, $15,400(154 \times 100)$ time series are generated for the NSR and SSR flows entering Saskatchewan. These streamflow series along with current and increased irrigation area scenarios are fed into $\mathrm{SWAMP}_{\mathrm{SK}}$ to simulate the system performance under changing conditions.

\subsection{Integrated Evaluation of Human and Environmental Needs}

A set of indicators are used to represent the performance of the water resource system under changing upstream flow and irrigation expansion conditions. In brief, annual NBs for hydropower and irrigated agriculture sectors and their sum are used to represent sectorial and provincial NBs, respectively. The long-term annual hydropower, irrigated agriculture and provincial NBs estimated by the SWAMP $P_{S K}$ during the observed period, $1980-2010$, are $\$ 305 \mathrm{M}, \$ 15 \mathrm{M}$ and $\$ 320 \mathrm{M}$, respectively.

It is challenging to directly evaluate the impact of changing upstream conditions on downstream environmental needs in the SRD. However, it is clear that alterations in the flow regime entering the SRD can affect delta's hydrographic networks and concentrations of nutrients and dissolved oxygen, which in turn, can affect the aquatic and terrestrial ecosystems [54,65]. For instance, disconnections between wetlands and main river channel can limit the accessibility to spawning areas for fishes and nesting success of waterfowl [66,67]. For our analysis, we focused on three ecohydrological indicators, namely the magnitude of the long-term annual SR peak flow, interannual variability in timing of the SR peak flow, as well as Surface Water Coverage Area (SWCA), which can affect the delta's ecosystem. In brief, changes in the magnitude of the long-term SR peak flow can affect the transportation of sediments and nutrients as well as the form and extension of hydrographic networks [65]. The interannual variability in timing of the annual peak flow represents flood rhythmicity and predictability [54]. It is shown in the literature that nonrhythmic floods can negatively affect the biodiversity and productivity of aquatic species [68]. Therefore, standard deviation of the annual peak flow timing entering the delta over 31 years is used to represent flood rhythmicity. Moreover, it was recently shown that reductions in the SWCA can limit the connectivity between lakes, wetlands, and main river flow, and degrade water quality in isolated water bodies [65]. Here, we used the following relationship between delta's SWCA in $\mathrm{km}^{2}$ and SR flow discharge $\left(\mathrm{m}^{3} / \mathrm{s}\right)$ : SWCA $=1.76 \times \mathrm{SR}^{0.63}$ obtained in [69] to estimate the SWCA during the ice-free season (May to October). The long-term discharge and timing of the annual peak SR flow entering the delta, as well as SWCA are, respectively, $1051 \mathrm{~m}^{3} / \mathrm{s}$, week 23 and $77 \mathrm{~km}^{2}$ during 1980-2010 (data were obtained from Water Survey of Canada gauge 05KD003 between 1980 and 2010).

\section{Trade-Offs between Upstream and Downstream}

In this section, trade-offs between upstream economic production and downstream environment are explored. For the sake of simplicity, the results are presented under all possible changes in water availability (154 flow conditions) to identify overall vulnerabilities as well as three specific flow conditions to represent the changes in system performance due to irrigation expansion. These specific flow conditions represent dry ( $25 \%$ decrease in long-term annual flow volume and 4 weeks earlier peak flow timing), historical (no change in long-term annual flow volume and peak flow timing), as well as wet ( $25 \%$ increase in long-term flow volume and 4 weeks later peak flow timing) water availability conditions. 


\subsection{The Effect of Changing Water Availability and Irrigation Practice on Upstream Economy}

Figure 2 shows the expected long-term sectorial and provincial annual NBs for current (left panel) and expanded irrigation areas (right panel) under changing upstream annual flow volume and peak flow timing. For each upstream streamflow conditions, the expected long-term NBs are calculated by averaging annual NBs over 100 realizations and 31-year simulation period. This figure shows that the agriculture sector is not considerably sensitive to changes in upstream flow conditions under current irrigation area. However, if irrigation area increases by $400 \%$, this sector becomes sensitive to changes in upstream flow volume and peak flow timing. This implies that the sector's performance is fairly stable under current irrigation area, but it might fluctuate drastically if irrigation area increases under changing flow conditions. Regarding the hydropower, the comparison between left and right panels shows that hydropower production is more sensitive to changes in upstream flow volume than peak flow timing or irrigation expansion. Therefore, there is no tangible trade-offs between hydropower and irrigation sectors. The provincial NB is more sensitive to changes in upstream flow volume under current irrigation area (similar to the hydropower NB). However, as the irrigation area increases, the long-term provincial NBs become sensitive to changes in the agriculture NB values as well.

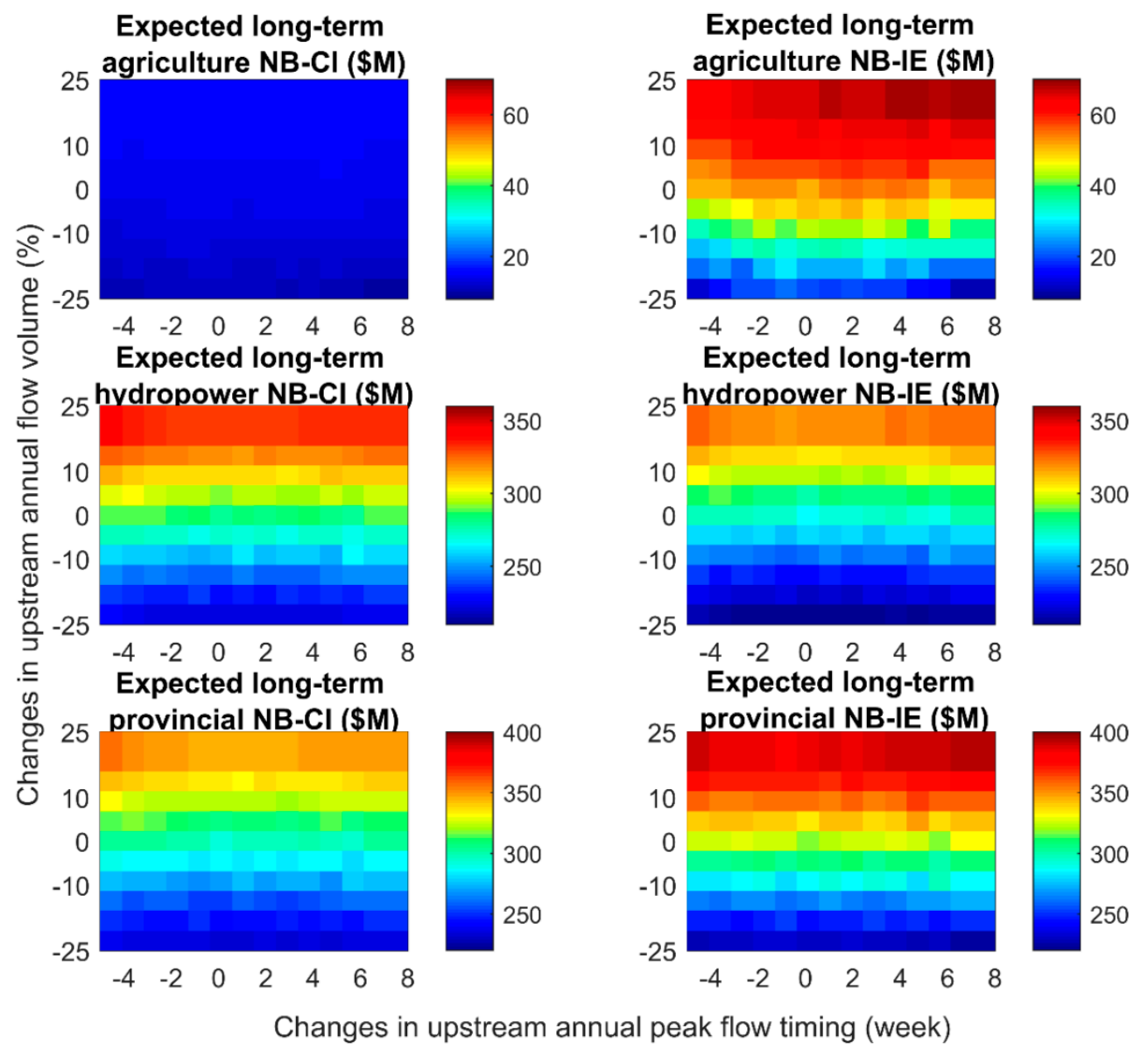

Figure 2. Expected long-term sectorial and provincial Net Benefits (NBs) under current irrigation (CI; left panel) and irrigation expansion (IE; right panel) scenarios as well as changing upstream South Saskatchewan River (SSR) and North Saskatchewan River (NSR) flow conditions.

Here, we estimated the percentage of change in sectorial and provincial annual NBs due to irrigation expansion under dry, historical, and wet upstream flow conditions. For this purpose, for each streamflow realization under the specific streamflow conditions and irrigation scenario, we estimated long-term annual sectorial and provincial NBs. Accordingly, we fitted the Empirical Cumulative Distribution Function (ECDF) to the long-term annual NBs (i.e., 100 values) under current and irrigation 
expansion scenarios. Considering the two ECDFs, for each percentile (non-exceedance probability), we estimated the percentage of change in long-term annual NBs due to irrigation expansion using the following equation:

$$
\Delta(p)=\frac{q_{p, I E}-q_{p, C I}}{q_{p, C I}} \times 100 \%
$$

where $\Delta(p)$ shows the percentage of change in long-term annual NB due to irrigation expansion for each percentile $(p) . q_{p, I E}$ and $q_{p, C I}$ are the quantiles of long-term annual NB, respectively, under irrigation expansion $(I E)$ and current irrigation $(C I)$ area corresponding to $p$.

Figure 3 shows the estimated percentage of change in long-term annual sectorial and provincial NBs as a result of irrigation expansion under dry, historical and wet upstream flow conditions. Considering the left panel, it is obvious that expanding irrigation areas by $400 \%$ does not necessarily lead to same percentage of increase in agricultural NBs. In fact, the magnitude of increase in agriculture NBs strongly depends on the considered upstream flow conditions. While agricultural production can almost reach its maximum level under wet upstream flow conditions, it may decrease significantly under dry upstream flow conditions. The middle panel shows that the maximum reduction in hydropower production due to irrigation expansion is less than $6 \%$ and it occurs under dry upstream flow conditions. This confirms that there is no tangible competition between hydropower and agriculture sectors when irrigation area is increased. Right panel shows that the impact of irrigation expansion on provincial NB is positive and it can increase provincial NB by maximum $18 \%$. However, there is a small chance that irrigation expansion might reduce provincial NBs under dry upstream flow conditions, when both agricultural productivity and hydropower have their lowest productions.

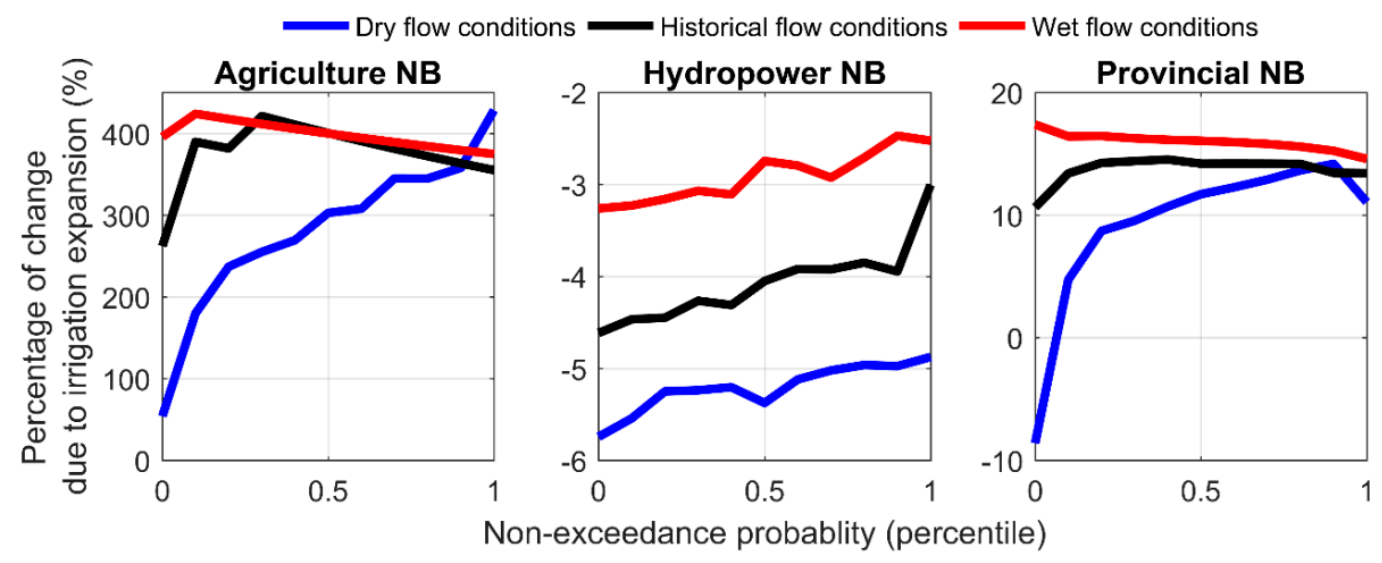

Figure 3. Percentage of change in long-term annual agriculture, hydropower and provincial NBs due to irrigation expansion under dry, historical and wet upstream flow conditions.

\subsection{Impacts on Downstream Environment}

In this section, we explored the impact of changing upstream flow conditions and irrigation expansion on the downstream environment of the delta. Similar to Section 4.1, here, we show the results for considered ecohydrological indicators under all possible changes in upstream flow as well as three specific flow conditions. Figure 4 shows the expected long-term annual SR peak flow $\left(\mathrm{m}^{3} / \mathrm{s}\right)$, expected standard deviation in SR peak flow timing (week), and expected long-term SWCA $\left(\mathrm{km}^{2}\right)$ under current (left) and expanded irrigation (right) areas. The expected long-term SR peak flow magnitude entering the delta under each upstream flow conditions and agriculture scenario is calculated by averaging the annual SR peak flow magnitude over 100 realizations and 31-year simulation period. As is apparent, the long-term annual SR peak flow magnitude is sensitive to changes in upstream flow volume than peak flow timing. Moreover, irrigation expansion can reduce the SR peak flow magnitude entering the delta, in particular under high upstream flow volume and late peak flow timing. This reduction in SR peak flow can negatively affect the connectivity of water bodies as well as sediment and nutrient 
transport in the delta. Furthermore, we calculated the standard deviation of annual peak SR flow timing over 31 years and averaged it over 100 realizations to represent changes in expected interannual variability in the SR peak flow timing. Figure 4 shows that the expected interannual variability in the SR peak flow timing is sensitive to the combination of changes in upstream flow volume, peak flow timing and irrigation expansion. In particular, an increase in upstream irrigation water withdrawal can increase the expected interannual variability and reduce flood predictability, which can adversely affect certain fish species that are habituated to peak flows in certain weeks of the year. Similar to previous indicators, the expected long-term SWCA corresponding to each streamflow condition and irrigation scenario is calculated by averaging annual SWCA over 31 years and 100 streamflow realization. As is apparent, the SWCA in the SRD is highly sensitive to changes in upstream flow conditions. An increase in irrigation water withdrawals can slightly reduce the SWCA under high upstream flow conditions.

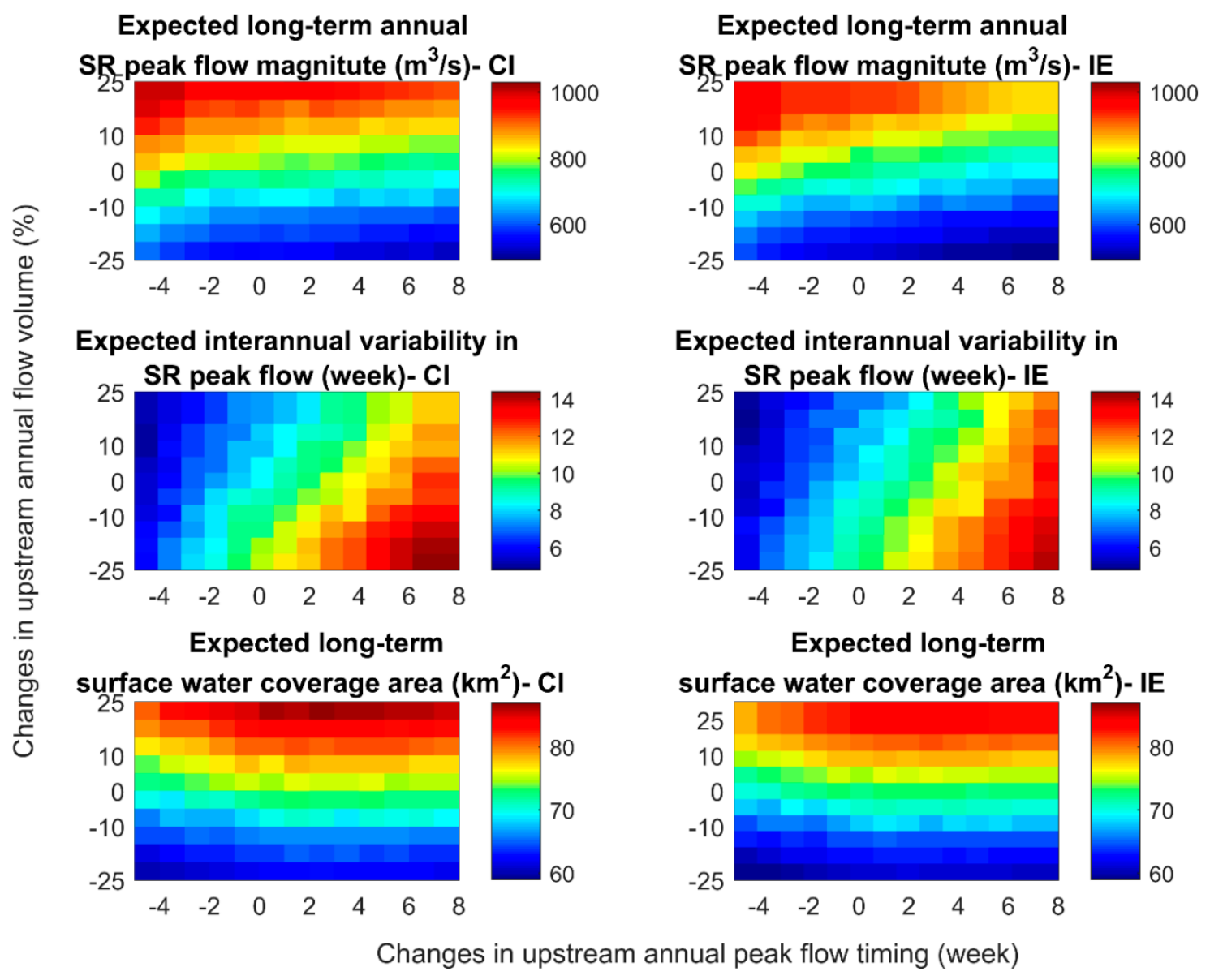

Figure 4. Expected long-term annual SR peak flow magnitude $\left(\mathrm{m}^{3} / \mathrm{s}\right.$; top row), expected interannual variability in SR peak flow timing (week; middle row), and expected long-term Surface Water Coverage Area (SWCA) ( $\mathrm{km}^{2}$; bottom row) in the SRD under current (CI; left) and irrigation expansion (IE; right) scenarios and changing upstream streamflow conditions.

Similar to the analyses for upstream economy, here we estimated the percentage of change in the ecohydrological characteristics of the delta due to irrigation expansion under dry, historical and wet upstream flow conditions. Thus, for each specific streamflow conditions, we fitted the ECDFs to 100 values of the considered ecohydrological indicator, obtained under current and irrigation expansion scenarios. Accordingly, $\Delta(p)$ for each streamflow conditions is calculated using Equation (1), where $q_{p, I E}$ and $q_{p, C I}$ represent the quantiles of the considered indicator under irrigation expansion and current irrigation area, respectively. Overall, considering each panel in Figure 5, it is clear that irrigation expansion can affect the ecohydrological characteristics of the delta; however, the intensity of 
the impacts depends on the considered upstream flow conditions. For instance, the largest negative impacts are seen under wet upstream flow conditions. Moving from left to right, it can be understood that the pattern and magnitude of alternations in the characteristics of the delta are not necessarily similar for different indicators. For instance, while irrigation expansion reduces the long-term SR peak flow volume and SWCA by less than $10 \%$, it can increase the interannual variability in peak SR flow timing up to $36 \%$ in the SRD.

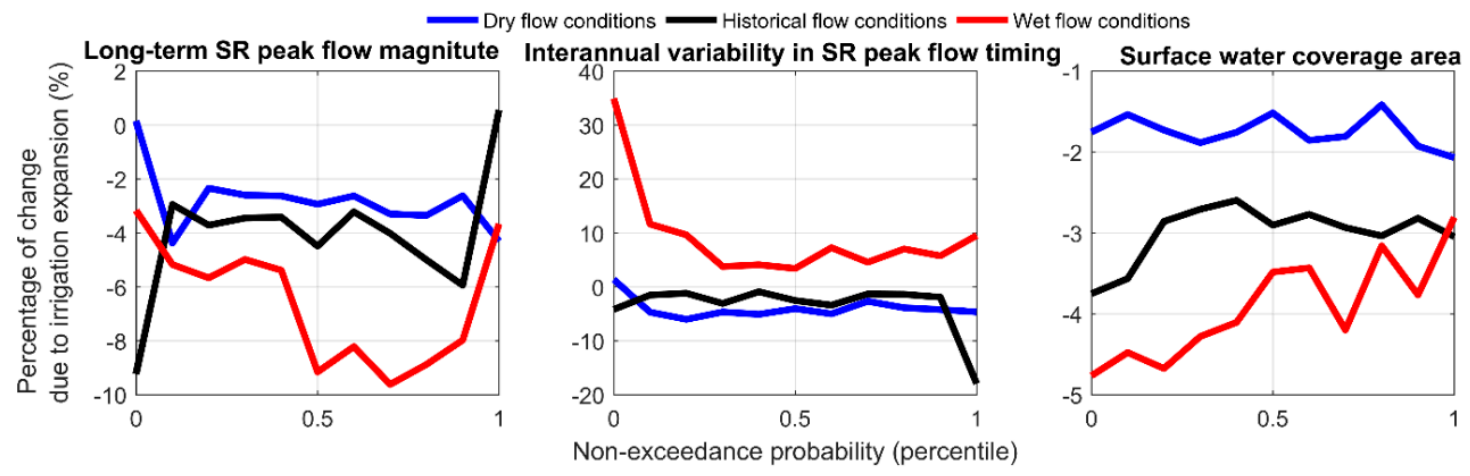

Figure 5. Percentage of change in the long-term SR peak flow magnitude, interannual variability in SR peak flow timing, as well as SWCA due to irrigation expansion under dry, historical and wet upstream flow conditions.

The potential impact of irrigation expansion on upstream economy and downstream characteristics of the delta under three specific upstream flow conditions are summarized in Table 2. The results indicate that irrigation expansion can slightly reduce hydropower production but boost provincial economy under changing upstream flow conditions. This, however, can reduce long-term peak flow volume and SWCA, and alter the rhythmicity of the peak flows in the delta, which can potentially affect the aquatic and terrestrial ecosystems. Ultimately, such changes in the environmental conditions could negatively affect the livelihoods of local residents, which depend on fishing, hunting and trapping, and might cause tensions between upstream and downstream communities. This implies that the business-as-usual operational policies and priorities might not be able to accommodate water supply for expanded irrigation and meet downstream environmental needs under changing upstream flow conditions. In the following section we comment on few research directions that can improve water management planning in this region.

Table 2. Percentage of change in sectorial and provincial economy as well as ecohydrological characteristics of the delta due to irrigation expansion under three specific water availability conditions.

\begin{tabular}{lccccccccc}
\hline \multirow{2}{*}{ Indicator } & \multicolumn{6}{c}{ Percentage of Change Due to Irrigation Expansion (\%) } \\
\cline { 2 - 10 } & \multicolumn{3}{c}{ Dry Flow Conditions } & \multicolumn{1}{c}{ Historical Flow Conditions } & \multicolumn{3}{c}{ Wet Flow Conditions } \\
\cline { 2 - 10 } & Min & Mean & Max & Min & Mean & Max & Min & Mean & Max \\
\hline Long-term annual agriculture NB & 54 & 280 & 420 & 262 & 375 & 420 & 375 & 397 & 420 \\
Long-term annual hydropower NB & -6 & -5 & -5 & -5 & -4 & -3 & -3 & -3 & -3 \\
Long-term annual provincial NB & -9 & 9 & 14 & 11 & 14 & 15 & 15 & 16 & 18 \\
Long-term SR peak flow & -5 & -3 & 0 & -10 & -4 & 0 & -10 & -7 & -3 \\
Interannual variability in SR peak & -6 & -4 & 2 & -18 & -4 & -1 & 4 & 10 & 36 \\
flow timing & -2 & -2 & -2 & -4 & -3 & -3 & -5 & -4 & -3 \\
Long-term SWCA & & & & & & & &
\end{tabular}

\section{Discussion}

Considering the changes in water availability and increase in water demand conditions, it is very likely that competitions between upstream human activities and downstream environmental needs will increase in the future [70]. Therefore, new regional water management strategies are 
required to support socio-economic developments while protecting ecosystems under changing natural and anthropogenic conditions. Nevertheless, identifying such management strategies is not trivial. For instance, relevant to our case study, relationships between upstream water availability and downstream delta's hydrographic networks, water quality and ecosystem health are not yet well understood and represented to inform decision-making [71,72]. As a first step towards addressing this challenge, a coupled water quantity and quality model should be developed to represent the human-water system dynamics from upstream to downstream. In brief, the water quantity module should represent interactions between water availability and demand conditions and their impact on downstream hydrographic networks. The water quality module should represent land and instream water quality conditions spatially and temporally. This model can help estimating allocable water to different water users dynamically. In parallel, continuous ecosystem-related data should be collected to better understand ecosystem needs and support building relationships between water and ecosystem conditions $[73,74]$.

Changes in climate and anthropogenic conditions will likely affect the performance of various water resource systems in the future [75]. Nevertheless, the identification of sectorial and overall system vulnerabilities heavily depends on the frameworks, used for impact assessments [76]. The common approach to evaluate the impact of changing climate conditions on water resource systems is based on a cascade of models, called "scenario-led" framework [77-79]. As the outputs of climate models, downscaling techniques and hydrological models are uncertain, the total uncertainty in projected system performance using this framework can be large [80-82]. In particular, climate models are not able to fully represent the characteristics of precipitation such as extreme rainfall values, which are critical for water management [83-87]. Moreover, different downscaling techniques might provide divergent signs of change in climate conditions and inconsistent system performances at finer spatiotemporal scales $[88,89]$. In response to these challenges, "scenario-led" frameworks have been recently developed to depict the water system performance under possible climate conditions [90-94]. Yet, the results of stress tests depend on the approach used for generation of stochastic climate scenarios [95]. Moreover, the results of vulnerability assessments are still uncertain, particularly if hydrological model are used for projection of streamflow series [96]. Recently, "fully scenario-neutral" frameworks are developed to generate possible streamflow series without using climate and hydrological models [51,97]. Similar to climate-based impact assessments, the revealed system vulnerabilities using fully scenario-neutral frameworks also depend on the approach, with which streamflow series are generated [98]. Thus, both scenario-led and scenario-neutral impact assessment frameworks need to be improved to reasonably represent system vulnerabilities and tipping points in the future. Moreover, these two frameworks can be combined to holistically identify sectorial and overall system vulnerabilities under different combinations of changing conditions (e.g., changes in water availability, climate, water demand and management policies) [58]. To facilitate decision-making under uncertainty, these possible future conditions can be weighted to provide a notion of their probability of occurrence in the future, e.g., using Bayesian approach, based on historical observations, paleorecords and stakeholders' viewpoints about future and management policies $[99,100]$.

The decisions of local stakeholders about water and land management practices can affect water system dynamics at the regional scale. However, stakeholders often have different business plans, values and viewpoints, which might hinder adoption of management practices or cause water conflicts between upstream and downstream stakeholders. Therefore, there is a need to engage with stakeholders and understand their viewpoints, land-use experiences and priorities about water and environment and incorporate them in water management decisions [101-104]. For instance, relevant to our case study, indigenous communities in the delta can provide great knowledge about natural environmental conditions, system hotspots and critical time of the year for aquatic and terrestrial species [66]. This qualitative knowledge should be analyzed and used to better represent human-water system dynamics and/or to develop water management scenarios. For this purpose, Q-methodology can be used to identify distinct stakeholder viewpoints in the region [105]. Content analysis can be used to interpret 
stakeholders' narratives to better understand relationships between stakeholder viewpoints and a series of psychological and non-psychological parameters [106]. Accordingly, various approaches, e.g., rule-based algorithms, can be used to convert this information into quantitative knowledge to be used in water system models, and impact assessment framework, noted above. Multi-layer decision-support tools, with different levels of complexity and details matching with participants background, should be developed and used for community engagements in water system discussions and analyses [107,108]. This can help finding water management decisions that are acceptable for multiple stakeholders.

\section{Conclusions}

Human activities over the past few decades have put enormous pressure on freshwater environments across the globe. In brief, socio-economic developments, weak land and water management decisions and changes in climate conditions have altered natural streamflow regime, which are critical for sustaining freshwater environments. This paper illustrates the potential competitions between upstream human and downstream environmental needs in Saskatchewan, Canada. Water in Saskatchewan is used for various socio-economic activities and passes through the Saskatchewan River Delta, one of the largest inland deltas in North America. The water resource system in Saskatchewan may face water security challenges due to changes in upstream flow conditions and provincial plans to increase irrigated agricultural areas. Our analyses showed that the agricultural sector is not sensitive to changes in upstream flow conditions under current irrigation areas. Moreover, there is a small trade-off between hydropower generation and agriculture production, and overall irrigation expansion can boost provincial economy under changing upstream flow conditions. However, irrigation expansion can alter the magnitude and timing of the annual peak flow entering the delta and affect delta's surface water coverage area under changing upstream flow conditions. Such changes can potentially affect hydrographic networks, sediment and nutrient transports and water quality in delta's water bodies, which can negatively affect delta's ecosystems. This example illustrates the emerging challenges for regional water management under changing conditions. Here, we discussed that addressing these challenges requires a set of developments to better understand and represent human-water system dynamics, e.g., interactions between human water use, water quantity, quality and ecosystem needs, across multiple scales. Moreover, impact assessment frameworks should be improved to better represent water system vulnerabilities and adaptation pathways under changing natural and anthropogenic conditions. Finally, stakeholders' viewpoints in upstream and downstream should be understood and incorporated in management decisions to ensure successful adoption of water and land management practices.

Funding: This research received no external funding.

Acknowledgments: The author would like to thank the constructive comments of four anonymous reviewers.

Conflicts of Interest: The author declares no conflict of interest.

\section{References}

1. Lytle, D.A.; Poff, N.L. Adaptation to natural flow regimes. Trends Ecol. Evol. 2004, 19, 94-100. [CrossRef]

2. Vörösmarty, C.J.; Green, P.; Salisbury, J.; Lammers, R.B. Global water resources: Vulnerability from climate change and population growth. Science 2000, 289, 284-288. [CrossRef]

3. Abell, R.; Thieme, M.L.; Revenga, C.; Bryer, M.; Kottelat, M.; Bogutskaya, N.; Coad, B.; Mandrak, N.; Balderas, S.C.; Bussing, W.; et al. Freshwater Ecoregions of the World: A New Map of Biogeographic Units for Freshwater Biodiversity Conservation. BioScience 2008, 58, 403-414. [CrossRef]

4. Syvitski, J.P.; Vörösmarty, C.J.; Kettner, A.J.; Green, P. Impact of humans on the flux of terrestrial sediment to the global coastal ocean. Science 2005, 308, 376-380. [CrossRef]

5. Meybeck, M. Global analysis of river systems: From Earth system controls to Anthropocene syndromes. Philos. Trans. R. Soc. Lond. Ser. B Biol. Sci. 2003, 358, 1935-1955. [CrossRef] 
6. Vörösmarty, C.J.; McIntyre, P.B.; Gessner, M.O.; Dudgeon, D.; Prusevich, A.; Green, P.; Glidden, S.; Bunn, S.E.; Sullivan, C.A.; Liermann, C.R.; et al. Global threats to human water security and river biodiversity. Nature 2010, 467, 555-561. [CrossRef]

7. Carlisle, D.M.; Wolock, D.M.; Meador, M.R. Alteration of streamflow magnitudes and potential ecological consequences: A multiregional assessment. Front. Ecol. Environ. 2011, 9, 264-270. [CrossRef]

8. Nazemi, A.; Wheater, H.S. On inclusion of water resource management in Earth system models-Part 2: Representation of water supply and allocation and opportunities for improved modeling. Hydrol. Earth Syst. Sci. 2015, 19, 63-90. [CrossRef]

9. Foley, J.A.; DeFries, R.; Asner, G.P.; Barford, C.; Bonan, G.; Carpenter, S.R.; Chapin, F.S.; Coe, M.T.; Daily, G.C.; Gibbs, H.K.; et al. Global consequences of land use. Science 2005, 309, 570-574. [CrossRef]

10. DeFries, R.; Eshleman, K.N. Land-use change and hydrologic processes: A major focus for the future. Hydrol. Process. 2004, 18, 2183-2186. [CrossRef]

11. Poff, N.L.; Zimmerman, J.K. Ecological responses to altered flow regimes: A literature review to inform the science and management of environmental flows. Freshw. Biol. 2010, 55, 194-205. [CrossRef]

12. Novotny, V. Water Quality: Prevention, Identification and Management of Diffuse Pollution; Van Nostrand-Reinhold: New York, NY, USA, 1994.

13. Fisher, B.; Turner, R.K.; Morling, P. Defining and classifying ecosystem services for decision making. Ecol. Econ. 2009, 68, 643-653. [CrossRef]

14. Gober, P.; Wheater, H.S. Socio-hydrology and the science-policy interface: A case study of the Saskatchewan River basin. Hydrol. Earth Syst. Sci. 2014, 18, 1413-1422. [CrossRef]

15. Barkham, J.P. Environmental needs and social justice. Biodivers. Conserv. 1995, 4, 857-868. [CrossRef]

16. Winpenny, J. Managing Water as an Economic Resource; Routledge: Abingdon-on-Thames, UK, 2005.

17. Acreman, M. Ethical aspects of water and ecosystems. Water Policy 2001, 3, 257-265. [CrossRef]

18. Garrick, D.E.; Hall, J.W.; Dobson, A.; Damania, R.; Grafton, R.Q.; Hope, R.; Hepburn, C.; Bark, R.; Boltz, F.; De Stefano, L.; et al. Valuing water for sustainable development. Science 2017, 358, 1003-1005. [CrossRef]

19. Acreman, M.C.; Dunbar, M.J. Defining environmental river flow requirements? A review. Hydrol. Earth Syst. Sci. Discuss. 2004, 8, 861-876. [CrossRef]

20. Wei, J.; Wei, Y.; Western, A. Evolution of the societal value of water resources for economic development versus environmental sustainability in Australia from 1843 to 2011. Glob. Environ. Chang. 2017, 42, 82-92. [CrossRef]

21. Glantz, M. (Ed.) Creeping Environmental Problems and Sustainable Development in the Aral Sea Basin; Cambridge University Press: Cambridge, UK, 1999.

22. Ghaheri, M.; Baghal-Vayjooee, M.H.; Naziri, J. Lake Urmia, Iran: A summary review. Int. J. Salt Lake Res. 1999, 8, 19-22. [CrossRef]

23. Zarghami, M. Effective watershed management; case study of Urmia Lake, Iran. Lake Reserv. Manag. 2011, 27, 87-94. [CrossRef]

24. Ashraf, S.; AghaKouchak, A.; Nazemi, A.; Mirchi, A.; Sadegh, M.; Moftakhari, H.R.; Hassanzadeh, E.; Miao, C.-Y.; Madani, K.; Baygi, M.M.; et al. Compounding effects of human activities and climatic changes on surface water availability in Iran. Clim. Chang. 2018, 152, 379-391. [CrossRef]

25. Hassanzadeh, E.; Zarghami, M.; Hassanzadeh, Y. Determining the main factors in declining the Urmia Lake level by using system dynamics modeling. Water Resour. Manag. 2012, 26, 129-145. [CrossRef]

26. Karbassi, A.; Bidhendi, G.N.; Pejman, A.; Bidhendi, M.E. Environmental impacts of desalination on the ecology of Lake Urmia. J. Great Lakes Res. 2010, 36, 419-424. [CrossRef]

27. AghaKouchak, A.; Norouzi, H.; Madani, K.; Mirchi, A.; Azarderakhsh, M.; Nazemi, A.; Nasrollahi, N.; Farahmand, A.; Mehran, A.; Hasanzadeh, E. Aral Sea syndrome desiccates Lake Urmia: Call for action. J. Great Lakes Res. 2015, 41, 307-311. [CrossRef]

28. Alborzi, A.; Mirchi, A.; Moftakhari, H.; Mallakpour, I.; Alian, S.; Nazemi, A.; Hassanzadeh, E.; Mazdiyasni, O.; Ashraf, S.; Madani, K.; et al. Climate-informed environmental inflows to revive a drying lake facing meteorological and anthropogenic droughts. Environ. Res. Lett. 2018, 13, 084010. [CrossRef]

29. Viviroli, D.; Buytaert, W.; Greenwood, G.B.; Hamlet, A.F.; Koboltschnig, G.; Lorentz, S.; Schädler, B.; Schreier, H.; Schwaiger, K.; Vuille, M.; et al. Climate change and mountain water resources: Overview and recommendations for research, management and policy. Hydrol. Earth Syst. Sci. 2011, 15, 471-504. [CrossRef]

30. Arnell, N.W. Climate change and global water resources. Glob. Environ. Chang. 1999, 9, S31-S49. [CrossRef] 
31. Milly, P.C.; Dunne, K.A.; Vecchia, A.V. Global pattern of trends in streamflow and water availability in a changing climate. Nature 2005, 438, 347. [CrossRef]

32. Murdoch, P.S.; Baron, J.S.; Miller, T.L. Potential effects of climate change on surface-water quantity in North America1. J. Am. Water Resour. Assoc. 2000, 36, 347-366. [CrossRef]

33. Whitehead, P.G.; Wilby, R.L.; Battarbee, R.W.; Kernan, M.; Wade, A.J. A review of the potential impacts of climate change on surface water quality. Hydrol. Sci. J. 2009, 54, 101-123. [CrossRef]

34. Nazemi, A.; Wheater, H.S. On inclusion of water resource management in Earth system models-Part 1: Problem definition and representation of water demand. Hydrol. Earth Syst. Sci. 2015, 19, 33-61. [CrossRef]

35. Mimikou, M.A.; Baltas, E.; Varanou, E.; Pantazis, K. Regional impacts of climate change on water resources quantity and quality indicators. J. Hydrol. 2000, 234, 95-109. [CrossRef]

36. Bates, B.; Kundzewicz, Z.; Wu, S. Climate Change and Water; Intergovernmental Panel on Climate Change Secretariat: Geneva, Switzerland, 2008.

37. Schröter, D.; Cramer, W.; Leemans, R.; Prentice, I.C.; Araújo, M.B.; Arnell, N.W.; Bondeau, A.; Bugmann, H.; Carter, T.R.; Gracia, C.A.; et al. Ecosystem service supply and vulnerability to global change in Europe. Science 2005, 310, 1333-1337. [CrossRef]

38. Pomeroy, J.W.; De Boer, D.; Martz, L.W. Hydrology and Water Resources of Saskatchewan; University of Saskatchewan Centre for Hydrology Report: Saskatoon, SK, Canada, 2005; pp. 1-15.

39. Partners for the Saskatchewan River Basin. From the Mountains to the Sea: Summary of the State of the Saskatchewan River Basin; Partners for the Saskatchewan River Basin: Saskatoon, SK, Canada, 2009; pp. 1-172.

40. Baschuk, M. Effects of Water-Level Management on the Abundance and Habitat Use of Waterfowl and Marsh Birds in the Saskatchewan River Delta, Manitoba, Canada. Master's Thesis, University of Manitoba, Winnipeg, MB, Canada, 2010.

41. Pomeroy, J.W.; Fang, X.; Williams, B. Impacts of Climate Change on Saskatchewan's Water Resources; University of Saskatchewan Centre for Hydrology Report: Saskatoon, SK, Canada, 2009; pp. 1-46.

42. Harder, P.; Pomeroy, J.W.; Westbrook, C.J. Hydrological resilience of a Canadian Rockies Headwaters basin subject to changing climate, extreme weather and forest management. Hydrol. Process. 2015, 29, 3905-3924. [CrossRef]

43. Saskatchewan Irrigation Projects Association. Lake Diefenbaker Irrigation Benefits Evaluation. 2008. Available online: http://www.irrigationsaskatchewan.com/SIPA_old160701/tti_v1-chap3.pdf (accessed on 25 August 2019).

44. Hassanzadeh, E. Integrated Management of Water Resource Systems under Changing Water Availability, Policy, and Irrigation Expansion Plans. Ph.D. Thesis, University of Saskatchewan, Saskatoon, SK, Canada, 2016.

45. Saskatchewan Water Security Agency (SWSA). 2012. Available online: https://www.wsask.ca/ (accessed on 25 August 2019).

46. Saskatchewan Water Security Agency (SWSA). Saskatchewan Hydrology and Groundwater Services. Lake Diefenbaker Reservoir Operations Context and Objectives; Saskatchewan Water Security Agency: Moose Jaw, SK, Canada, 2012; p. 47.

47. Saskatchewan Water Security Agency (SWSA). Lake Diefenbaker ROP Development; Scenario and Performance Measures Documentation; Saskatchewan Water Security Agency: Moose Jaw, SK, Canada, 2015; pp. 1-13.

48. Smith, N.D.; Slingerland, R.L.; Pérez-Arlucea, M.; Morozova, G.S. The 1870s avulsion of the Saskatchewan River. Can. J. Earth Sci. 1998, 35, 453-466. [CrossRef]

49. Asante, C.K.; Jardine, T.D.; Van Wilgenburg, S.L.; Hobson, K.A. Tracing origins of waterfowl using the Saskatchewan River Delta: Incorporating stable isotope approaches in continent-wide waterfowl management and conservation. Condor Ornithol. Appl. 2017, 119, 261-274. [CrossRef]

50. Martz, L.; Bruneau, J.; Rolfe, J.T. Climate Change and Water: SSRB, Final Technical Report; GIServices, University of Saskatchewan: Saskatoon, SK, Canada, 2007.

51. Nazemi, A.; Wheater, H.S. How can the uncertainty in the natural inflow regime propagate into the assessment of water resource systems? Adv. Water Resour. 2014, 63, 131-142. [CrossRef]

52. Saskatchewan Ministry of Agriculture. Irrigation: Lake Diefenbaker's Unfinished Business; Saskatchewan Ministry of Agriculture: Regina, SK, Canada, 2008. 
53. Hassanzadeh, E.; Elshorbagy, A.; Wheater, H.; Gober, P.; Nazemi, A. Integrating supply uncertainties from stochastic modeling into integrated water resource management: Case study of the Saskatchewan River basin. J. Water Resour. Plan. Manag. 2015, 142, 05015006. [CrossRef]

54. Hassanzadeh, E.; Elshorbagy, A.; Nazemi, A.; Jardine, T.D.; Wheater, H.; Lindenschmidt, K.E. The ecohydrological vulnerability of a large inland delta to changing regional streamflows and upstream irrigation expansion. Ecohydrology 2017, 10, e1824. [CrossRef]

55. Hassanzadeh, E.; Elshorbagy, A.; Wheater, H.; Gober, P. Managing water in complex systems: An integrated water resources model for Saskatchewan, Canada. Environ. Model. Softw. 2014, 58, 12-26. [CrossRef]

56. Saskatchewan Water Security Agency. Water Use and Allocation: Regulatory Requirements for the Diversion and Use of Water; Saskatchewan Water Security Agency: Moose Jaw, SK, Canada, 2015.

57. Nazemi, A.; Wheater, H.S.; Chun, K.P.; Elshorbagy, A. A stochastic reconstruction framework for analysis of water resource system vulnerability to climate-induced changes in river flow regime. Water Resour. Res. 2013, 49, 291-305. [CrossRef]

58. Hassanzadeh, E.; Elshorbagy, A.; Wheater, H.; Gober, P. A risk-based framework for water resource management under changing water availability, policy options, and irrigation expansion. Adv. Water Resour. 2016, 94, 291-306. [CrossRef]

59. Panofsky, H.A.; Brier, G.W. Some Applications of Statistics to Meteorology; State University, College of Earth and Mineral Sciences: State College, PA, USA, 1968.

60. Rood, S.B.; Pan, J.; Gill, K.M.; Franks, C.G.; Samuelson, G.M.; Shepherd, A. Declining summer flows of Rocky Mountain rivers: Changing seasonal hydrology and probable impacts on floodplain forests. J. Hydrol. 2008, 349, 397-410. [CrossRef]

61. Rood, S.B.; Samuelson, G.M.; Weber, J.K.; Wywrot, K.A. Twentieth-century decline in streamflows from the hydrographic apex of North America. J. Hydrol. 2005, 306, 215-233. [CrossRef]

62. Shepherd, A.; Gill, K.M.; Rood, S.B. Climate change and future flows of Rocky Mountain rivers: Converging forecasts from empirical trend projection and downscaled global circulation modelling. Hydrol. Process. 2010, 24, 3864-3877. [CrossRef]

63. Farjad, B.; Gupta, A.; Marceau, D.J. Hydrological regime responses to climate change for the 2020s and 2050s periods in the Elbow River watershed in southern Alberta, Canada. In Environmental Management of River Basin Ecosystems; Springer: Cham, Switzerland, 2015; pp. 65-89.

64. Wheater, H.; Gober, P. Water security in the Canadian Prairies: Science and management challenges. Philos. Trans. R. Soc. Lond. A Math. Phys. Eng. Sci. 2013, 371, 20120409. [CrossRef] [PubMed]

65. MacKinnon, B.D.; Sagin, J.; Baulch, H.M.; Lindenschmidt, K.-E.; Jardine, T.D. Influence of hydrological connectivity on winter limnology in floodplain lakes of the Saskatchewan River Delta, Saskatchewan. Can. J. Fish. Aquat. Sci. 2015, 73, 140-152. [CrossRef]

66. Abu, R.; Reed, M.G.; Jardine, T.D. Using two-eyed seeing to bridge Western science and Indigenous knowledge systems and understand long-term change in the Saskatchewan River Delta, Canada. Int. J. Water Resour. Dev. 2019, 1-20. [CrossRef]

67. Smith, N.D.; Morozova, G.S.; Gibling, M.R. Channel enlargement by avulsion-induced sediment starvation in the Saskatchewan River. Geology 2014, 42, 355-358. [CrossRef]

68. Jardine, T.D.; Bond, N.R.; Burford, M.A.; Kennard, M.J.; Ward, D.P.; Bayliss, P.; Davies, P.M.; Douglas, M.M.; Hamilton, S.K.; Melack, J.M.; et al. Does flood rhythm drive ecosystem responses in tropical riverscapes? Ecology 2015, 96, 684-692. [CrossRef]

69. Sagin, J.; Sizo, A.; Wheater, H.S.; Jardine, T.D.; Lindenschmidt, K.E. A water coverage extraction approach to track inundation in the Saskatchewan River Delta, Canada. Int. J. Remote Sens. 2015, 36, 764-781. [CrossRef]

70. Wheater, H.S.; Gober, P. Water security and the science agenda. Water Resour. Res. 2015, 51, 5406-5424. [CrossRef]

71. Settele, J.; Scholes, R.; Betts, R.A.; Bunn, S.; Leadley, P.; Nepstad, D.; Overpeck, J.; Taboada, M.A.; Fischlin, A.; Moreno, J.M.; et al. Terrestrial and inland water systems. In Climate Change 2014 Impacts, Adaptation and Vulnerability: Part A: Global and Sectoral Aspects; Cambridge University Press: Cambridge, UK, 2015; pp. 271-360.

72. Cosgrove, W.J.; Loucks, D.P. Water management: Current and future challenges and research directions. Water Resour. Res. 2015, 51, 4823-4839. [CrossRef] 
73. Liu, J.; Liu, Q.; Yang, H. Assessing water scarcity by simultaneously considering environmental flow requirements, water quantity, and water quality. Ecol. Indic. 2016, 60, 434-441. [CrossRef]

74. Dawes, S.S.; Vidiasova, L.; Parkhimovich, O. Planning and designing open government data programs: An ecosystem approach. Gov. Inf. Q. 2016, 33, 15-27. [CrossRef]

75. IPCC. 2019. Available online: https://www.ipcc.ch/2019/ (accessed on 25 August 2019).

76. Wilby, R.L. Evaluating climate model outputs for hydrological applications. Hydrol. Sci. J. 2010, 55, 1090-1093. [CrossRef]

77. Hagemann, S.; Chen, C.; Clark, D.B.; Folwell, S.; Gosling, S.N.; Haddeland, I.; Hanasaki, N.; Heinke, J.; Ludwig, F.; Voss, F.; et al. Climate change impact on available water resources obtained using multiple global climate and hydrology models. Earth Syst. Dyn. 2013, 4, 129-144. [CrossRef]

78. Wilby, R.L.; Whitehead, P.G.; Wade, A.J.; Butterfield, D.; Davis, R.J.; Watts, G. Integrated modelling of climate change impacts on water resources and quality in a lowland catchment: River Kennet, UK. J. Hydrol. 2006, 330, 204-220. [CrossRef]

79. Teng, J.; Vaze, J.; Chiew, F.H.; Wang, B.; Perraud, J.M. Estimating the relative uncertainties sourced from GCMs and hydrological models in modeling climate change impact on runoff. J. Hydrometeorol. 2012, 13, 122-139. [CrossRef]

80. Gibson, C.A.; Meyer, J.L.; Poff, N.L.; Hay, L.E.; Georgakakos, A. Flow regime alterations under changing climate in two river basins: Implications for freshwater ecosystems. River Res. Appl. 2005, 21, 849-864. [CrossRef]

81. Arthington, A.H.; Balcombe, S.R. Extreme flow variability and the 'boom and bust'ecology of fish in arid-zone floodplain rivers: A case history with implications for environmental flows, conservation and management. Ecohydrology 2011, 4, 708-720. [CrossRef]

82. Prudhomme, C.; Davies, H. Assessing uncertainties in climate change impact analyses on the river flow regimes in the UK. Part 2: Future climate. Clim. Chang. 2009, 93, 197-222. [CrossRef]

83. Maurer, E.P.; Duffy, P.B. Uncertainty in projections of streamflow changes due to climate change in California. Geophys. Res. Lett. 2005, 32. [CrossRef]

84. Brown, C.; Wilby, R.L. An alternate approach to assessing climate risks. Eos Trans. Am. Geophys. Union 2012, 93, 401-402. [CrossRef]

85. Hallegatte, S.; Shah, A.; Lempert, R.; Brown, C.; Gill, S. Investment Decision Making under Deep Uncertainty-Application to Climate Change; The World Bank: Washington, DC, USA, 2012.

86. Wilby, R.L.; Dessai, S. Robust adaptation to climate change. Weather 2010, 65, 180-185. [CrossRef]

87. Chen, H.; Xu, C.Y.; Guo, S. Comparison and evaluation of multiple GCMs, statistical downscaling and hydrological models in the study of climate change impacts on runoff. J. Hydrol. 2012, 434, 36-45. [CrossRef]

88. Maraun, D.; Widmann, M. Statistical Downscaling and Bias Correction for Climate Research; Cambridge University Press: Cambridge, UK, 2018.

89. Hassanzadeh, E.; Nazemi, A.; Adamowski, J.F.; Nguyen, T.H.; Nguyen, V.-T.-V. Quantile-based downscaling of rainfall extremes: Notes on methodological functionality, associated uncertainty and application in practice. Adv. Water Resour. 2019, 131, 103371. [CrossRef]

90. Poff, N.L.; Brown, C.M.; Grantham, T.E.; Matthews, J.H.; Palmer, M.A.; Spence, C.M.; Wilby, R.L.; Haasmoot, M.; Mendoza, G.F.; Dominique, K.C.; et al. Sustainable water management under future uncertainty with eco-engineering decision scaling. Nat. Clim. Chang. 2016, 6, 25. [CrossRef]

91. Brown, C.; Ghile, Y.; Laverty, M.; Li, K. Decision scaling: Linking bottom-up vulnerability analysis with climate projections in the water sector. Water Resour. Res. 2012, 48. [CrossRef]

92. Prudhomme, C.; Wilby, R.L.; Crooks, S.; Kay, A.L.; Reynard, N.S. Scenario-neutral approach to climate change impact studies: Application to flood risk. J. Hydrol. 2010, 390, 198-209. [CrossRef]

93. Lempert, R.J.; Groves, D.G. Identifying and evaluating robust adaptive policy responses to climate change for water management agencies in the American west. Technol. Forecast. Soc. Chang. 2010, 77, 960-974. [CrossRef]

94. Chun, K.P.; Wheater, H.S.; Nazemi, A.; Khaliq, M.N. Precipitation downscaling in Canadian Prairie Provinces using the LARS-WG and GLM approaches. Can. Water Resour. J. 2013, 38, 311-332. [CrossRef]

95. Culley, S.; Bennett, B.; Westra, S.; Maier, H.R. Generating realistic perturbed hydrometeorological time series to inform scenario-neutral climate impact assessments. J. Hydrol. 2019, 576, 111-122. [CrossRef] 
96. Najafi, M.R.; Moradkhani, H.; Jung, I.W. Assessing the uncertainties of hydrologic model selection in climate change impact studies. Hydrol. Process. 2011, 25, 2814-2826. [CrossRef]

97. Borgomeo, E.; Farmer, C.L.; Hall, J.W. Numerical rivers: A synthetic streamflow generator for water resources vulnerability assessments. Water Resour. Res. 2015, 51, 5382-5405. [CrossRef]

98. Nazemi, A.; Zaerpour, M.; Hassanzadeh, E. Sensitivity of Bottom-up Vulnerability Assessments of Water Supply Systems to Regional Streamflow Generation under Changing Conditions. J. Water Resour. Plan. Manag. 2019, in press. [CrossRef]

99. Taner, M.Ü.; Ray, P.; Brown, C. Incorporating Multidimensional Probabilistic Information into Robustness-Based Water Systems Planning. Water Resour. Res. 2019, 55, 3659-3679. [CrossRef]

100. Van Staveren, M. Uncertainty and Ground Conditions: A Risk Management Approach; CRC Press: Boca Raton, FL, USA, 2018.

101. Blöschl, G.; Bierkens, M.F.; Chambel, A.; Cudennec, C.; Destouni, G.; Fiori, A.; Kirchner, J.W.; McDonnell, J.J.; Savenije, H.H.; Sivapalan, M.; et al. Twenty-three unsolved problems in hydrology (UPH)—A community perspective. Hydrol. Sci. J. 2019, 64, 1141-1158. [CrossRef]

102. Margerum, R.D.; Robinson, C.J. Collaborative partnerships and the challenges for sustainable water management. Curr. Opin. Environ. Sustain. 2015, 12, 53-58. [CrossRef]

103. He, H.; Chen, A.; Yin, M.; Ma, Z.; You, J.; Xie, X.; Wang, Z.; An, Q. Optimal Allocation Model of Water Resources Based on the Prospect Theory. Water 2019, 11, 1289. [CrossRef]

104. Nazemi, A.; Madani, K. Urban water security: Emerging discussion and remaining challenges. Sustain. Cities Soc. 2019, 41, 925-928. [CrossRef]

105. Hassanzadeh, E.; Strickert, G.; Morales-Marin, L.; Noble, B.; Baulch, H.; Shupena-Soulodre, E.; Lindenschmidt, K.E. A framework for engaging stakeholders in water quality modeling and management: Application to the Qu'Appelle River Basin, Canada. J. Environ. Manag. 2019, 231, 1117-1126. [CrossRef] [PubMed]

106. Bradford, L.; Thapa, A.; Duffy, A.; Hassanzadeh, E.; Strickert, G.; Noble, B.; Lindenschmidt, K.-E. Incorporating Social Dimensions in Hydrological and Water-Quality Modeling to Evaluate the Effectiveness of Agricultural Beneficial Management Practices in a Prairie River Basin. Environ. Sci. Pollut. Res. 2019. Accepted.

107. Malard, J.J.; Inam, A.; Hassanzadeh, E.; Adamowski, J.; Tuy, H.A.; Melgar-Quiñonez, H. Development of a software tool for rapid, reproducible, and stakeholder-friendly dynamic coupling of system dynamics and physically-based models. Environ. Model. Softw. 2017, 96, 410-420. [CrossRef]

108. McIntosh, B.S.; Ascough, J.C., II; Twery, M.; Chew, J.; Elmahdi, A.; Haase, D.; Harou, J.J.; Hepting, D.; Cuddy, S.; Jakeman, A.J. Environmental decision support systems (EDSS) development-challenges and best practices. Environ. Model. Softw. 2011, 26, 1389-1402. [CrossRef] 